\title{
HVMANITAS
}

\section{Os miliários como fontes históricas e arqueológicas}
Autor(es):
Mantas, Vasco Gil

Publicado por: Imprensa da Universidade de Coimbra

URL

persistente:

URI:http://hdl.handle.net/10316.2/27385

DOI:

DOI:http://dx.doi.org/10.14195/2183-1718_64_9

Accessed : $\quad$ 26-Apr-2023 10:15:11

A navegação consulta e descarregamento dos títulos inseridos nas Bibliotecas Digitais UC Digitalis, UC Pombalina e UC Impactum, pressupõem a aceitação plena e sem reservas dos Termos e Condições de Uso destas Bibliotecas Digitais, disponíveis em https://digitalis.uc.pt/pt-pt/termos.

Conforme exposto nos referidos Termos e Condições de Uso, o descarregamento de títulos de acesso restrito requer uma licença válida de autorização devendo o utilizador aceder ao(s) documento(s) a partir de um endereço de IP da instituição detentora da supramencionada licença.

Ao utilizador é apenas permitido o descarregamento para uso pessoal, pelo que o emprego do(s) título(s) descarregado(s) para outro fim, designadamente comercial, carece de autorização do respetivo autor ou editor da obra.

Na medida em que todas as obras da UC Digitalis se encontram protegidas pelo Código do Direito de Autor e Direitos Conexos e demais legislação aplicável, toda a cópia, parcial ou total, deste documento, nos casos em que é legalmente admitida, deverá conter ou fazer-se acompanhar por este aviso. 
humanitas

\section{Vol. LXIV \\ 2012}

IMPRENSA DA UNIVERSIDADE DE COIMBRA

COIMBRA UNIVERSITY PRESS 
In Memoriam Géza Alföldy

\title{
OS MILIÁRIOS COMO FONTES HISTÓRICAS E ARQUEOLÓGICAS
}

\author{
Vasco Gil Mantas \\ Universidade de Coimbra (CECH/FCT)
}

\begin{abstract}
Resumo
Os miliários não se limitavam a facultar indicações práticas aos viajantes no mundo romano, ainda que a indicação de distâncias fosse a sua função principal. Representaram um elemento próprio de uma paisagem humanizada, na qual a sua presença e as epígrafes que ostentavam contribuiam para a difusão de valores culturais característicos da civilização romana. Por isso, constituem elementos essenciais não só para reconstituir os traçados viários, mas também para ajudar a traçar a história das estradas romanas, assunto nem sempre dos mais fáceis.
\end{abstract}

Palavras chave: Miliários; Vias; Romanização; Cultura

\begin{abstract}
:
Milestones provided more than practical information to travellers in the Roman world, even though their main function was to present information on distances. They represent a very characteristic element of a humanized landscape, in which their presence and displayed epigraphs contributed to the spread of cultural values proper to Roman civilization. Thus, milestones constitute not only crucial elements for reconstructing the layout of the road network but also help to trace the history of Roman roads, something which is not always easy to accomplish.
\end{abstract}

Key words: Milestones; Roads; Romanization; Culture

Claude de Bronseval, um beneditino francês que viajou largamente por Portugal e Espanha empenhado na visitação de institutos da Ordem efectuada por Dom Edme Saulieu entre 1531 e 1533, deixou-nos um meticuloso relato diário desse peregrinar, fundamental para o conhecimento da rede viária 
da época e das condições, quase sempre difíceis, em que se viajava na Península Ibérica. Numa dessas jornadas, que os levou a Tancos, refere o eclesiástico francês o seguinte, a propósito da zona entre Venda das Mestas e o Tejo: A notar que nestes desertos onde não há estradas nem caminhos, uma vez que eles não são frequentados nem pelos homens, nem mesmo pelos animais (porque é uma região miseravelmente deserta), encontram-se espalhadas colunas de pedra levantadas para indicar o caminho aos viajantes. Doutra forma eles não saberiam onde ir e arriscar-se-iam talvez a serem vítimas dos incêndios que deflagram constantemente num e noutro lugar destes desertos. Diz-se que foi Júlio César Augusto quem ordenou a colocação destas colunas quando percorreu as Hispânias, pensando nos perigos que correriam aqueles que no futuro por lá passassem (Bronseval 1970: 501-502; Marques 1997: 91-121).

Esta passagem, a única em todo o relato em que se referem miliários, tem um interesse múltiplo, como testemunho do respeito pelos trabalhos viários da antiguidade romana, por definir lapidarmente a função principal dos miliários e a sua forma mais vulgar e, seguramente o mais importante, por confirmar a existência de marcos miliários numa região, a Charneca de Montargil, onde a sua autenticidade, apesar do testemunho de Francisco de Holanda confirmando a presença de calçadas romanas na zona (Holanda 1984: 27-28), foi posta em dúvida não poucas vezes (Encarnação 1984: 719, 725-726). O texto de Claude de Bronseval, redigido num Latim de acessível leitura, onde não faltam saborosas peripécias, conduz-nos neste caso directamente ao tema dos miliários como documentos fundamentais, quer do ponto de vista histórico, quer do ponto de vista arqueológico. Em relação ao primeiro aspecto a referência a Júlio César, reflectindo a titulatura presente nas inscrições dos marcos, comprova a existência de uma via romana importante e a identificação dos monumentos no terreno permite deduzir o traçado geral da estrada. Trata-se, portanto, de um eloquente e descomprometido testemunho do valor documental dos marcos miliários romanos.

Para que tenhamos uma ideia mais próxima do que significam os miliários como fontes históricas primárias basta referir que actualmente os miliários conservados ou conhecidos através de documentação escrita ou iconográfica ascendem a cerca de 10000 , pertencendo ao território português perto de 400, largamente concentrados nas grandes vias a norte do Douro. Sem descurar outros levantamentos realizados anteriormente nessa mesma zona, recordamos o importante trabalho de campo efectuado pelo Padre 
Martins Capela nos finais do século XIX, ainda hoje de consulta obrigatória para quem queira estudar as vias romanas da Calécia bracarense (Capela 1895), não obstante a existência de obras recentes dotadas de exaustivos catálogos (Colmenero et alii 2004). No território português a sul do Douro, outrora pertencente à Lusitânia, o número daqueles monumentos é muito mais reduzido, por razões que se relacionam em primeiro lugar com as características sócio-políticas da região, condicionadoras da rede viária.

As estradas, como todas as grandes obras de utilidade pública, tiveram especial projecção na ideologia do Estado romano, na época republicana e, consequentemente, durante o Império. Por isso mesmo, foram largamente utilizadas como símbolo quer da grandeza do Estado (Kleiner 1999: 182-192; Álvarez Martínez / Basarrate 2003: 255-276), quer do evergetismo estatal ao serviço da Res Publica, através da acção dos magistrados e do imperador. Mesmo nos dias do declínio definitivo do Império o discurso oficial insiste abertamente neste aspecto, como se verifica neste édito de Honório e Teodósio II, datado de 423: Os mesmos Augustos a Asclepiódotos, prefeito do pretório. Está longe de nós considerarmos a construção de vias públicas e de pontes e o trabalho nas calçadas consagradas pelos títulos de grandes imperadores como serviços públicos compulsivos de natureza servil. Por isso, nenhuma classe de homens, por mérito de qualquer elevada dignidade ou veneração, deve ser isenta da construção e reparação de estradas e pontes (Cod. Theod., 15, 3, 1). Os miliários, elementos fortes da paisagem viária, tiveram um lugar destacado neste imaginário facilmente desenvolvido uma vez que todos podiam partilhar quotidianamente das suas vantagens práticas.

Frequentemente representados, como outros símbolos viários, em emissões monetárias comemorativas, os miliários constituiam uma imagem civilizacional fortíssima, representando o poder unificador de Roma, real e mítico, através de mensagens simples e eficientes dispersas por um mundo que se estendia das margens sombrias do Mar do Norte até aos desertos do Mar Vermelho. Entre as diversas representações de miliários nos numismas da época imperial destacamos a figura do Miliarium Aureum presente nas moedas do imperador Filipe, o Árabe, comemorativas do milenário de Roma e dos jogos seculares que comemoraram o evento (Fig.1), usando o marco como forma de evidenciar o valor da data no percurso histórico de Roma (Arzone 2011: 77-92).

Como tantas vezes tem sido demonstrado, a civilização romana valorizou quanto pôde uma cultura da escrita e da informação. Os miliários estiveram 
no centro de tais práticas, aliando informações políticas e indicações de ordem prática, através de textos muito simples, normalmente, de forma a facilitar a leitura a quem se deslocava na estrada, ao que parece pela esquerda. Encontramos nestes monumentos a permanente mistura de auto-elogio do poder romano, tão evidente, por exemplo, nos arcos honoríficos (Wheeler 1964: 152-158; Pensa 1979: 19-27), e da Utilitas, concretizada através de epígrafes que exprimem da melhor forma a inquestionável capacidade romana para praticar uma arte da escrita pública, destinada aos ambientes abertos da rua e da estrada (Susini 1988: 105-124), facilmente assimilável mesmo pelos que liam mal. Esta circunstância confirma a enorme diferença existente entre a civilização romana e outras grandes civilizações, como a do Egipto faraónico, diferença essencial de que os próprios Romanos tiveram plena consciência, reflectida através de um sentimento de superioridade como o de Frontino ao comparar a inutilidade dos monumentos faraónicos e dos belos edifícios gregos com a utilidade evidente da arte construtiva romana, expressa pelos aquedutos (Frontino, De Aquae., 161).

Muito simplesmente, o miliário é um marco destinado a indicar distâncias. O Miliarium Aureum, mandado levantar por Augusto em 20 a.C., era um grande marco cilíndrico, colocado no Forum Romanum, perto do Templo de Saturno, junto à Rostra, no lado oposto ao Umbilicus Urbis. São provavelmente deste monumento, e não do Miliarium, o fragmento de mármore muito ornamentado que é indicado como tendo-lhe pertencido (Moro 1983: 77-80; Richardson 1992: 254). Seja como for, era a partir desta coluna que se contavam as distâncias entre Roma e as principais cidades do Império, monumento de que os conhecidos Vasos de Vicarello, com indicação das mansiones da via entre Cádis e Roma e respectivas distâncias, permitem imaginar o aspecto, do qual, na verdade, pouco sabemos (Hervás 1975: 14-160; Chevallier 1972: 46-49). Em Constantinopla existiu também

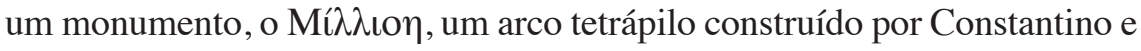
a partir do qual se contavam as distâncias de Constantinopla até às principais cidades do mundo romano (Müller-Wiener 1977: 216-218).

Esta prática de contar as distâncias a partir de um ponto definido persistiu e encontra-se hoje em muitos países, como na Itália, onde a contagem se faz a partir da colina do Capitólio, ou em Espanha, onde as estradas ditas radiais iniciam a contagem das distâncias na Porta do Sol, em Madrid (Fig.2). Outro processo muito utilizado, como na Inglaterra, foi o de contar as distâncias a partir das estações de correio, embora a tradição defenda que as distâncias eram estabelecidas a partir da London Stone, restos de 
um miliário que se conserva em Londres na Cannon Street e que durante a Idade Média se considerava como coração da cidade. Estes monumentos urbanos pertencem, pelas suas funções, ao grupo de indicadores viários, parte reduzida de um grupo muito maior e elemento destacado da paisagem viária, que eram os miliários.

A estradas constituiam um traço forte da paisagem, que ajudaram a construir, paisagem bastante complexa e da qual fazia parte uma significativa diversidade de padrões que lhe conferiam, simultaneamente, individualidade e unidade. Eis o que Giancarlo Susini escreveu sobre a epigrafia viaria: Come si è detto, l'iscrizione romana è uno degli elementi della cultura urbana: è piu facile recupararla dall'area di un abitato antico che dalla campagna, dove peró no mancano le pietre milliari lungo le strade, le iscrizioni tombali dai piccolo sepolcreti presso i paesi, $i$ villagi, le fattorie (vicii, pagi, villae) o più frequentemente presso santuari agresti o pastorali di tenace frequentazione già dalla protostoria (Susini 1982: 29-30). Entre estes monumentos não podemos deixar de recordar os marcos demarcatórios, por vezes substituídos por arcos marcando a fronteira, como sucede na Bética, onde os miliários da Via Augusta marcam a distância $a b$ arcu und incipit Baetica, assim como os mais modestos altares consagrados aos Lares Viales (Mantas 2010: 13-14).

Embora haja alguma reticência a propósito da denominação marco miliário, a verdade é que ela entrou definitivamente na terminologia arqueológica e foi ratificada pelo seu uso sistemático. Assim, um miliário é um indicador de distâncias, normalmente contadas em milhas romanas. Vejamos o que sobre eles escreveu Políbio: Os Romanos arranjaram esta estrada e marcaram-na cuidadosamente com marcos de oito em oito estádios, quer dizer, de milha em milha (Políbio 3, 39, 8)². Políbio refere-se aqui à Via Domitia, que unia o Ródano à Hispânia, não deixando dúvidas quanto às funções dos miliários: indicar distâncias medidas em milhas. Os primeiros miliários seguramente datados registados na Itália remontam ao século II a.C., podendo alguns deles relacionar-se com as reformas agrárias empreendidas nesse século (Salway 2001: 48-54), mas foi com Augusto que a balizagem das grandes estradas se tornou vulgar, inclusivamente no território lusitano (Fig.3).

Devemos advertir que os miliários nem sempre indicam as distâncias, como o nome sugere, em milhas. Com efeito, no norte da Gália e na Germânia, e talvez também nalguns casos na Britânia, as distâncias eram medidas em léguas (leugae), equivalentes a 2222 metros. Um dos 
relevos do monumento funerário dos Secundini, em Igel, perto de Trier, mostra um carro que passa ao lado de um marco onde se vê perfeitamente a indicação L IIII, ou seja, quatro léguas (Fig.4). Amiano Marcelino refere esta particularidade regionalista da balizagem viária, evidenciada na Tábua de Peutinger, cópia medieval de um mapa viário romano conservada na antiga Biblioteca Imperial de Viena de Áustria, através de uma uma anotação colocada junto a Lyon: usque hec le(u)gas (Amiano Marcelino Epit., 15, 2, 17; Chevallier 1972: 25, 39-40). A epigrafia também fornece provas de que nem sempre os miliários eram colocados sistematicamente de milha em milha, podendo sê-lo de cinco em cinco, neste caso denominados quinários, como esclarece um marco de Constâncio II: Viis munitis, pontibus refecti, recuperata re publica, quinarios lapides per Illyricum fecit, ab Atrante ad flumen Savum milia passus CCCXLVI (CIL III 3705).

Uma das questões que tem suscitado largas polémicas entre os especialistas é a do valor da milha nas vias romanas, valor para o qual não faltam ainda hoje propostas divergentes, nomeadamente para a Hispânia, onde o investigador espanhol Antonio Blázquez, em 1932, chegou a defender cinco valores diferentes para a milha, enquanto outros não hesitam em sugerir, para a mesma estrada, diferentes medidas (Blázquez 1932: 43-57; Morán 1949: 27). Mais recentemente, Rodríguez Colmenero e, em Portugal, Brochado de Almeida, consideram que o valor métrico da milha corresponde a $1666 \mathrm{e}$ 1600 metros, respectivamente (Colmenero et alii 2004: 44-47; Almeida 1979: 71). Na verdade, apesar da variedade de propostas existentes, por isso mesmo difíceis de aceitar, parece não haver qualquer razão sólida para admitir outro valor para a milha na Península Ibérica a não ser o valor normal de 1480 metros, desde logo sugerido pela referência de Políbio.

Estudos como os de Roldán Hervás e Pierre Sillières, sobre estradas contando com um avultado número de miliários, muitos deles ainda in situ, comprovam um valor médio sempre próximo de 1480 metros (Hervás 1975: 32-34; Sillières 1990: 58-63). Encontrámos o mesmo valor no itinerário Olisipo-Bracara, onde o miliário da Mealhada, com indicação da milha XII, foi encontrado a cerca de 18 quilómetros de Coimbra (CIL II 4640), ou o miliário do Rabaçal, que indica a milha VIII e que foi achado in situ a 12 quilómetros de Conimbriga (Mantas 1985: 159-167). No Alentejo não faltam também miliários comprovativos de que a milha romana utilizada era a milha normal, como se verifica, por exemplo, na via Ebora-Pax Iulia, em boa hora registada por Mário Saa (Saa 1963: 234-265; Carneiro 2008: 99-103). Este investigador não deixou de contribuir, através da sua 
conhecida imaginação provocatória, para a polémica do valor da milha, ao propor a desconcertante teoria de que o módulo da milha utilizada em cada estrada se determinava pela altura do fuste das colunas viárias dessa estrada. Assim, como o miliário de Nossa Senhora dos Prazeres (IRCP 666a), recolhido em 1951 por Saa e hoje conservado na Fundação Arquivo Paes Teles / Mário Saa, no Ervedal, mede 1,58 metros de altura, a milha teria 1580 metros de extensão (Saa 1956: 276).

Devemos ter em conta que a colocação dos miliários, sobretudo em zonas de terreno difícil, nem sempre se fazia com facilidade quando se cumpria o valor da milha, pelo que pequenas oscilações por excesso e por defeito são admissíveis, não justificando em nenhuma circunstância a existência de milhas locais. A localização dos miliários reflectia-se, frequentemente, na toponímia, o que permite controlar o valor da milha através das distancias indicadas. Muitas destas indicações referem a localização de mansiones ou mutationes, indicadas através da referência ao miliário associado. Assim acontece, por exemplo, na via entre Astorga e Tarragona, onde a estação denominada Ad Septimum Decimum (It. Ant., $452,4)$ se situa exactamente a 17 milhas de Tarragona, embora o sentido da descrição da via seja contrário ao da numeração dos miliários. Alguns topónimos actuais conservam a memória de miliários desaparecidos, como parece ser o caso de Achete (Ad Septimum), povoação a 11 quilómetros de Santarém, numa das estradas entre Scallabis e Collipo, por Pernes, distância que concorda facilmente com sete milhas romanas.

Passemos então às características físicas dos miliários. Os miliários mais antigos registados na Itália têm forma vagamente trapezoidal, destinados a serem fixados ao solo, ao lado da estrada. Evoluiram depois para formas mais elaboradas, das quais a mais vulgar é a coluna cilíndrica sem capitel, por vezes ligeiramente ovalisada, dotada de uma base cúbica solidária, quase sempre grosseira, destinada a facilitar a implantação do miliário (Sterpos 1971: 108-119; Kolb 2011: 17-28). A base e parte do fuste ficavam normalmente enterrados. Conhecem-se também miliários prismáticos, muito menos frequentes e quase sempre pertencentes ao Baixo Império. Todavia, foram também utilizados durante os primeiros tempos do Império, atingindo dimensões assinaláveis, como sucedeu na Lusitânia com os miliários de Augusto levantados na via entre Mérida e Ciudad Rodrigo, por Cória, e na estrada que desta partia em direcção à região da Guarda, como testemunha o miliário de Alfaiates, erradamente atribuído a Idanha-a- Velha (Lambrino 1956: 14-17), existindo também alguns de príncipes júlio-cláudios no sul de França (Grenier 1934: 70-71)³. 
A maior parte dos miliários possui uma inscrição gravada directamente sobre o fuste ou num campo epigráfico preparado, por vezes moldurado. Existe um grande número de miliários anepígrafos, sugerindo que a inscrição pode ter sido pintada, como muitas vezes sucedeu com a indicação da distância em miliários produzidos em série para a mesma estrada. O uso de inscrições pintadas nos miliários encontra-se confirmado em vários locais, assim como parece ter sido vulgar levantar marcos sem inscrição nas estradas secundárias, onde estes, aliás, eram menos numerosos. As dimensões dos marcos eram bastante diversas, rondando, em média, pelos dois metros de altura e uns 40 centímetros de diâmetro. De uma maneira geral os miliários do século IV são mais pequenos e têm menor diâmetro, ostentando inscrições quase sempre de medíocre qualidade. Os miliários levantados nas fronteiras das civitates podiam eventualmente atingir dimensões superiores à média dos restantes na respectiva estrada.

O material utilizado varia com os recursos da região atravessada pela estrada, conhecendo-se grupos de miliários abandonados junto a pedreiras ao lado da estrada (Torres 1995: 45-49), nalguns casos inacabados, noutros prontos para a colocação algures. Também se conhecem miliários talhados em materiais relativamente afastados do local do achado, sugerindo a existência de oficinas ocupadas em produzir em série de marcos destinados a balizar, ou rebalizar, uma determinada estrada ou troço de estrada, por exemplo dentro dos limites de uma cidade. A via Bracara-Cale, onde os miliários mais antigos remontam a Adriano sem o indicarem como construtor da estrada, parece ter sido alvo de uma operação desse tipo ao longo das suas 35 milhas, após uma alteração no seu troço final, a que pertence a Ponte da Pedra (Mantas 2000: 5-87). O estudo dos materiais e das pedreiras não deixará de facultar informações interessantes quanto a estas redes industriais e ao próprio traçado viário. Em Conimbriga, por exemplo, marcos em calcário de Ançã e de Porto de Mós e em grés de Leiria sugerem diversas oficinas, ou pelo menos, diversas pedreiras, comprovando simultaneamente que a cidade constituía um fulcro de correntes económicas e entroncamento de vias importantes (Mantas 1996: 312-322).

A reutilização de fustes de colunas como miliários é conhecida, embora não muito frequente. Um dos miliários achados há pouco tempo nas Almoínhas, em Loures, e de que se aguarda a publicação, foi gravado num fuste de coluna, prática quase sempre relacionada com miliários tardios. Bastante mais vulgar, e desde muito cedo, era a gravação de novas inscrições em miliários anteriores, picando as já existentes, dando origem 
a autênticos palimpsestos ou simplesmente adicionando a nova inscrição à original. Um miliário de Tácito, achado em Conimbriga, constitui um bom exemplo da primeira situação, nem sempre identificada (Mantas 1996: 312-315; Étienne/Fabre 1976: 17), a qual nada tem a ver com o hábito de regravar inscrições antigas, habitual entre os séculos XVI e XVIII, e que tantos problemas de leitura suscita aos epigrafistas contemporâneos.

A repartição e cronologia dos miliários é, naturalmente, da maior importância para o estudo da rede viária da época romana, mesmo quando, como sucede na maioria dos casos, os monumentos foram deslocados do seu local de achado, como aconteceu com os muitos marcos transportados para Braga entre os séculos XVI e XVIII e que no século XIX constituiam uma das atracções do Largo das Carvalheiras, pois hoje não é fácil determinar com exactidão a que via pertenciam, tanto mais que parte deles foram sujeitos a duvidosas operações de regravação (Capela 1895: 255-260; Wickert 1933: 442-443). Esta circunstância obriga a ter em conta, quase sempre, uma localização provável, difícil de confirmar e frequentemente sustentáculo de hipóteses nem sempre credíveis. A situação agrava-se sensivelmente quando os miliários foram submetidos a transformações, que quase sempre os desfiguraram, tendentes a facilitar a sua reutilização, transformações cujo limite extremo consistia na obliteração completa do monumento enquanto miliário, como aconteceu com o que existia em São Mamede de Infesta (CIL II 4735), perto do Porto, destruído para dele se fazer a base do cruzeiro do cemitério no próprio dia em que Martins Capela se deslocou a esta localidade para o estudar.

Não faltam por todo o lado miliários reutilizados das mais diversas formas, como suportes variados, pias para animais, poldras para atravessar ribeiros ou ainda como sarcófagos, a exemplo do sucedido com um grande miliário de Caracala achado em Soure, quebrado para facilitar a reutilização (Fig. 5), sem esquecer outras aplicações mais modernas, como sucedeu em Braga onde um miliário achado na Quinta das Goladas foi reutilizado como contrapeso de guindaste (Comércio 1985). Nalguns casos felizes os miliários foram apenas reutilizados como suporte, nomeadamente quando cristianizados como cruzeiros, de que o existente em São João do Campo, no Gerês, é um excelente exemplo, circunstância que muitas vezes os manteve perto do seu lugar de implantação original. A cristianização dos miliários, porém, também foi em determinadas circunstâncias muito prejudicial à sua conservação. Bom exemplo disso é o miliário dos Santos Mártires, perto de Tomar, colocado no século XVII numa edícula pertencente a um 
pequeno santuário rural relacionado com a lenda dos Mártires de Concórdia, estimulada por uma necrópole romana nas proximidades, miliário totalmente desgastado pelos crentes que raspavam a sua superfície para obter pó destinado a combater diversas maleitas (Luz 1642: 32-33).

O valor simbólico dos miliários fica assim confirmado, mesmo quando totalmente alheio ao seu contexto original, sobrevivendo como locais consagrados, sobretudo em pontos fulcrais da rede viária, como locais tradicionais de reunião dos representantes dos concelhos medievais e, naturalmente, como términos administrativos ou de propriedade. Alguns sobreviveram ao longo das estradas, mantendo a sua função de baliza viária durante o período medieval, como talvez se possa deduzir do seguinte documento régio: Defendimus ut nullus audeat taliar cum vallo carreiras vel stratas auctorizatas de concilio vel mutet marchos (Portugaliae Monumenta Historica 1856: 402). É de admitir que esta determinação incluída nos forais possa ter contribuída para conservar miliários ainda existentes junto às estradas medievais, ainda que seja possível tratar-se de simples marcos concelhios, alguns dos quais eram, seguramente, antigos marcos miliários. Desta forma, os miliários projectam-se como fontes históricas e arqueológicas muito para além do seu próprio tempo.

Vimos já que os miliários in situ não são frequentes, assim como a sua repartição geográfica é muito desigual. Com efeito, enquanto no Algarve apenas se conhece um miliário, o de Bias do Sul (IRCP 660), da estrada entre Balsa (Luz de Tavira) e Ossonoba (Faro), contam-se por centenas os que existem no território português a norte do Douro. Como explicar tal discrepância? É certo que o acaso dos achados arqueológicos pode interferir neste panorama, sobretudo quando se verifica falta de pedra em determinadas áreas, levando à reutilização sistemática e ao desaparecimento dos marcos, mas uma diferença tão marcada não pode explicar-se desta forma. O primeiro aspecto a reter neste caso é a diferença entre a Lusitânia e a Tarraconense, pois se a primeira não contava com guarnições permanentes a segunda dispôs sempre de tropas, o que se reflecte imediatamente na construção e manutenção das vias principais e no levantamento de miliários, mesmo quando não eram necessários, como forma de lealismo e propaganda.

Por outro lado, os miliários concentram-se nas grandes vias que interessavam, por esta ou por aquela razão, ao poder imperial, nomeadamente as que serviam o cursus publicus, o correio oficial, unindo os centros de poder provinciais, as guarnições e outros locais de interesse estratégico ou económico. São portanto, os grandes itinerários, que os miliários por vezes 
designam como viae militares, que merecem a atenção do poder central, delegando nas cidades os trabalhos viários da rede secundária. Como estes trabalhos eram particularmente caros não nos devemos admirar quer com a ausência de miliários em muitos traçados, quer com a sumária construção de muitas destas estradas. Mesmo vias de grande importância conheceram uma balizagem intermitente, como a já referida via estratégica entre os rios Atras e Save, na Ilíria, onde os marcos de Constâncio II foram levantados apenas de cinco em cinco milhas (CIL III 3705).

O longo itinerário entre Olisipo e Bracara, com uma extensão de 244 milhas romanas permite apreender rapidamente as razões que motivaram tão grandes desfasamentos na repartição dos miliários. Com efeito, a estrada facultou até agora um total de 45 marcos, existentes ou confirmados por fontes escritas, com uma distribuição típica. A norte do Douro, no troço Bracara-Cale (Porto), conhecem-se 22 miliários para um traçado de apenas 35 milhas, enquanto que para o percurso entre Cale e Olisipo, que ascende a 209 milhas, não se conhecem mais de 24 marcos, dos quais seis pertencem a Conimbriga, dois a Selium e quatro a Olisipo e arredores (Fig.6). As características próprias de cada província e a hierarquia das vias justifica este tipo de distribuição irregular, como Pierre Sillières demonstrou no seu exaustivo estudo das vias romanas das regiões meridionais de Espanha (Sillières 1990: 44-46).

Só as grandes vias conheceram balizagem sistemática, por vezes como na via Emerita-Asturica com um ponto de contagem único, neste caso a capital da Lusitânia, justificando a classificação como autêntica via (Torres 1995: 23-30; Hervás 2005: 21-22). Os miliários das estradas secundárias concentram-se junto às cidades, nos limites territoriais ou em pontos especialmente importantes do traçado, nomeadamente nas portelas, locais de travessia de rios (traiectus) ou portos, como em Alfeizerão, onde se acharam dois miliários da estrada Olisipo-Collipo-Conimbriga (Mantas 1986: $213-225)^{4}$.

Um aspecto da repartição dos miliários que tem causado alguma perplexidade e não poucas interpretações mais ou menos fantasiosas é o dos chamados ninhos de miliários, concentrações de marcos no mesmo local da estrada, com indicação da mesma milha. Claro que não referimos as pedreiras junto à estrada onde por vezes ficaram miliários apenas esboçados ou já prontos para a colocação, situação normal que se explica pelo simples abandono por imperfeição da pedra ou morte do imperador, sobretudo quando há diversos marcos do mesmo governante. Poderíamos 
ser tentados a explicar desta forma a situação que se verifica na Via Nova no sítio da Portela do Homem, onde existem 16 miliários, alguns dos quais de Caracala, solução que não nos parece completamente satisfatória. É possivel que neste ponto se tenham preparado os miliários de Caracala, mas tal facto não implica que no local não existissem diversos balizando a estrada, ainda que desnecessariamente do ponto de vista prático (Fig.7). Com efeito, é muito frequente encontrar no mesmo local, indicando a mesma milha, marcos de diferentes imperadores, referindo ou não trabalhos de manutenção da via e, quando tardios, muitas vezes sem indicação de distância, tornada redundante pela presença de outros contendo essa indicação fundamental. Esta generosidade na colocação de miliários constata-se, por razões evidentes, sobretudo em zonas militarizadas, como era a região atravessada pela Estrada da Geira.

A leitura das inscrições dos miliários não é isenta de dificuldades, assim como a fotografia dos mesmos se revela também difícil. Ainda segundo Susini, a forma mais ou menos cilíndrica dos miliários responderia a uma necessidade específica de legibilidade: Forse per tale congerie di motivi le iscrizione miliarie si svolgevano quasi tutte su superfici semicilindriche, tali cioè da farsi leggere da cavallo o dal carro senza rallentare la marcia (Susini 1988: 108). As epígrafes dos miliários facultam dois tipos de indicações fundamentais, umas de carácter político, outras de ordem prática. Estão no primeiro caso a denominação do imperador e a indicação da sua titulatura, enquanto que no segundo caso se contam as referências respeitantes à estrada e de maior interesse para os viajantes, especialmente as indicações de distância em relação às capita viarum ou a um limite determinado, assim como raras informações quanto a trabalhos viários.

$\mathrm{O}$ nome do imperador surge normalmente em nominativo, como sujeito, em dativo quando se trata de uma dedicatória honorífica ou em ablativo quando se pretende datar uma acção. Os miliários em dativo são muito raros no século I, vulgarizando-se no século III e predominando no século IV. Os marcos levantados no século V são muito poucos, por razões que se prendem com a instabilidade crescente e com as grandes dificuldades financeiras do Estado romano. A ausência de indicação de distâncias em miliários com indicação do nome do imperador em dativo levanta um problema algo complicado em torno da classificação desses marcos como autênticos miliários. Uma teoria muito difundida, elaborada por Pierre Salama, pretende que estes marcos sejam simples monumentos honoríficos a relacionar com o culto imperial (Salama 1951: 217; König 
1973: 419-427). Cremos que esta hipótese é demasiadamente simples, pois não é possivel duvidar da realização de trabalhos viários associados a muitos dos referidos miliários sem indicação de distância.

Na Hispânia, os miliários em dativo, anda que em pequeno número, surgem logo no século I, mas não antes do principado de Cláudio, não faltando exemplos para os séculos seguintes, por vezes em situações que não permitem duvidar da realização de trabalhos viários, alguns de grande envergadura, como cremos ter sucedido na estrada Bracara-Cale, onde todos os miliários de Adriano nomeiam o imperador em dativo. Para uma melhor interpretação destes monumentos julgamos necessário ter em conta a evolução do miliário no sentido da sua transformação em monumento honorífico, a interpretar no contexto da evolução sócio-política do Império. Talvez na base deste processo se encontrem os miliários aparentemente levantados para comemorar o início do governo de determinados imperadores, o que explica imediatamente alguns dos chamados ninhos de miliários, levando a um local frequentado, fora do ambiente urbano, uma prova de respeito pelo novo governante que, simultaneamente, servia para manter a população informada sobre quem regia os destinos do Império.

$\mathrm{Na}$ verdade, o texto inscrito nos miliários tornou-se progressivamente idêntico ao das inscrições honoríficas imperiais, suplantando o número destas no século IV. Atendendo às condições da época e à legislação que se conhece através do Código de Teodósio, podemos considerar os trabalhos viários em si mesmos como uma forma de homenagear o imperador, nas mesmas condições da oferta do ouro coronário, transformado em imposto obrigatório (Lot 19682: 103), pelo que estes padrões viárias, desde que encontrados junto de uma estrada, devem ser contados entre os verdadeiros miliários, anda que com as reservas necessárias. A língua utilizada nas inscrições foi, na maior parte dos casos, o Latim, de regra na parte ocidental do Império, ainda que no sul da Itália ocorram alguns, raros, bilíngues, com as inscrições em Latim e em Grego. Na parte oriental do Império muitas das inscrições são em Grego, mas não faltam miliários com as epígrafes em língua latina. No caso de trabalhos viários simultâneos em diversas estradas a apresentação dos nomina imperatoris, fixada pelo governador provincial, era a mesma (Pekary 1968: 85-86). Ainda assim, sobretudo em miliários isolados, levantados por iniciativa das cidades, é normal encontrar discrepâncias, não só na titulatura, como no próprio nome do imperador, particularmente nos miliários do século IV. 
A titulatura é do maior interesse, quer como fonte histórica de ordem geral, quer como forma de indicar, por vezes com grande precisão, a data do levantamento do marco ou da execução de trabalhos viários. Estes eram comemorados com frequência através de colunas semelhantes a miliários, como sucedeu, por exemplo, na ponte de Chaves. Estes monumentos, todavia, não podem ser classificado como miliários, pois aqui a intenção é exclusivamente comemorativa e de propaganda. As colunas que se encontram na ponte são cópias das originais, uma das quais se recuperou no leito do Tâmega há alguns anos (Tranoy 1981: 60-61; Silva 1981-1982: 83-96). Outro aspecto particularmente importante das titulaturas é o de permitirem restituir com elevado grau de segurança inscrições mal conservadas ou mal lidas. No século IV tornam-se muito frequentes as fórmulas iniciais $\mathrm{D}$ (omino) $\mathrm{N}($ ostro $)$ e $\mathrm{B}($ ono $) \mathrm{R}$ (eipublicae) $\mathrm{N}($ ato $)$. Esta segunda fórmula e as suas variantes são muito vulgares nos miliários prismáticos. O plural DD.NN surge frequentemente, quando se trata de Augustos e de Césares governando em conjunto de acordo com o sistema tetrárquico introduzido por Diocleciano, ou quando há dois co-imperadores.

A mensagem política inserida nos miliários era cuidadosamente programada, como a dos numismas, inserindo-se na titulatura três grupos de elementos: a denominação e filiação do imperador; os cognomina $e x$ virtute; as funções e poderes, com especial destaque para o exercício do poder tribunício, a tribunicia potestas, cuja numeração é da maior utilidade do ponto de vista cronológico (Fig.8).

A forma como se identificava o imperador permite apreender aspectos significativos da orientação política da sua governação. Os miliários de Caracala, por vezes de grandes dimensões, incluem normalmente uma longa lista de ascendentes na sua filiação, fazendo-a remontar ao imperador Nerva. É evidente que esta pretendida descendência do pai adoptivo de Trajano é absolutamente fictícia, revelando a preocupação da dinastia iniciada por Septímio Severo em afirmar uma legitimidade discutível, no mínimo, e a continuidade dos Antoninos num Império que começava a sofrer alterações profundas. Outro caso que revela evidentes intenções políticas é o que se reflecte nos miliários de Tibério, onde a titulatura é de extrema sobriedade, confirmando uma das facetas desta personalidade plena de contrastes, pois Tibério procurou limitar as distinções que lhe eram dirigidas, nomeadamente os títulos oficiais.

Os miliários de Tibério omitem normalmente o título imperator e a respeito das reticências legalistas de Tibério, inclusive quanto à recusa 
formal do imperador em aceitar o título de Pai da Pátria e à sua relutância em assumir o de Augusto, escreveu Suetónio o seguinte: Praenomen quoque imperatoris cognomenque patris patriae et civicam in vestibulo coronam recusavit; ac ne Augusti quidem nomen, quamquam hereditarium, nullis nisi ad reges ac dynastas epistulis addidit (Suetónio, Tib., 26). Nestes casos, como no anterior, estamos em pleno domínio dos contributos históricos fornecidos pelas inscrições dos miliários. Transcrevemos o texto do miliário achado em Ul, um dos mais antigos marcos de Tibério registados na Península Ibérica (Almeida 1956: 111-113; Mantas 1996: 336-340): Tib(erius). Caesar. Divi. Aug(usti) / filius. Augustus / Pontifex. Maxum(us) / Trib(unicia) Potestat(e). XXV / (milia passuum) XII. Este marco, datado do período entre 1 de Julho de 23 e 30 de Junho de 24, sugere, quando relacionado com os marcos de Calígula achados na Mealhada e em Coimbra (CIL II 4639, 4640), que este troço da estrada entre o Douro e o Mondego foi construído ou renovado a partir do norte, onde aquele rio constituía a fronteira setentrional da Lusitânia.

Os agnomina imperiais são, por outro lado, de grande importância quanto à história militar, ainda que por vezes correspondam apenas a títulos pouco mais que honoríficos. Tornam-se vulgares a partir do século III, referindo vitórias sobre este ou aquele povo das fronteiras do Império: Germanico; Britannico; Parthico; Arabico; Adiabenico; Sarmatico. Por vezes o epíteto é valorizado com o adjectivo Maximus. Nos miliários do século IV ocorrem frequentemente fórmulas muito gerais, que não podemos deixar de relacionar com as intermináveis guerras civis e usurpações que marcaram o século e que, segundo alguns historiadores, terão contribuído decisivamente para a irreparável decadência do Estado romano (Demandt 1984: 695; Goldsworthy 2010)5 . Entre tais fórmulas destacamos uma das mais usuais, Victori ac triumphatori semper Augusto, por vezes associada à expressão terra marique. Estas fórmulas admitem ligeiras alterações, mas o sentido permanece.

As indicações viárias seguem-se às de ordem política, embora alguns miliários indiquem a distância, raramente aliás, na primeira linha da inscrição, como sucede com os miliários de Adriano da via Italica-Emerita (Sillières 1990: 137-140). A indicação mais importante para os viajantes era, como é lógico, a distância a percorrer, normalmente contada em relação ao início da estrada, ainda que alguns miliários contemplem referências aos termini viarum. O numeral que exprime a indicação da distância é precedido, embora nem sempre assim aconteça, das siglas M.P. (Milia Passuum), M, ou P.M. A indicação das distâncias é praticamente geral nos miliários do século I, 
tornando-se menos frequente, por razões que já referimos, nos marcos mais recentes. Sublinhamos, todavia, que os padrões viárias colocados depois da primeira balizagem receberam em muitos casos indicação de distâncias nos seus letreiros, acompanhando os monumentos mais antigos.

As indicações a propósito da execução de trabalhos viários, frequentes em determinadas vias, são quase sempre lacónicas para as estradas da Hispânia. A par de algumas formas menos lapidares, a maior parte destas referências resume-se a um verbo, normalmente facere, reficere ou restituere. Damos dois exemplos de inscrições mais explícitas, ambas provenientes do território português. A primeira achou-se na Portela do Homem, no Gerês: Imp. Tito. Caesare. Divi / Vesp. f. Vespasiano Aug / Pont. Max. Trib. Pot IX / Imp. XV. P. P. Cos VIII / Caesare. Divi. Vesp.f. [---]. Cos. VII / C. Calpetano. Rantio / Quirinale. Valerio / Festo. Leg. Aug. Pro Pr / Via Nova. A Brac / M. P. XXXIIII (CIL II 4838). A segundo pertence a um miliário conservado em Braga: Imp. Caesar. C Iulius / Verus. Maximinus. P. F. / Aug. Germanic. Max. Dac / Max. Sarmatic. Max. Pont / Max. Trib. Potestatis / V Imp. VII. P. P. Cos. Pro / Cos. et G. Iulius. Verus / Max. Nobilissimus Caesa[r] / Germanic. Max. Dacic. / Max. Sarmatic. Max. Princeps / Iuventutis. filius. D. N. Imp. C. / Iuli Ver. Maximini. P. F. Aug / vias. et. pontes / tempore / vetustatis. conlapsos / restituerunt. curante. Q. Decio . leg. Augg. Pr. Pr. / A Brac. Aug. M. P. I (CIL II 4756).

A primeira destas inscrições, do ano 80, informa-nos da construção da Via Nova e permite conhecer o nome do magistrado responsável, legado do imperador Tito. Na linha cinco deparamos com uma rasura, seguramente testemunhando a damnatio memoriae de Domiciano, idêntica à que existe no chamado Padrão dos Povos da ponte de Chaves, cuidadosamente reproduzida quando se executou a cópia que nela permanece. Esta operação, ordenada pelo Senado, deve ter sido executada na mesma altura em que os miliários de Nerva foram levantados na via Bracara-Tude, certamente no ano 97, como se pode deduzir de um marco em Rubiães, Coura (CIL II 6226).

A segunda epígrafe, longa e redundante, pertence a um miliário de Maximino e Máximo, do ano 238, atribuível à via Bracara-Tude, a qual parece ter sido objecto de uma grande reparação que incluiu a reconstrução de pontes. Esta hipótese é reforçada pelo facto dos miliários dos mesmos governantes e do mesmo período identificados na Via Nova não referirem a reconstrução da mesma. Embora longe da precisão de certas epígrafes de miliários italianos, que chegam a indicar o custo das obras efectuadas 
e o seu financiamento (Pekary 1968: 93-95; Duncan-Jones 1974: 124-125, 157-160), ambas as inscrições se revelam fontes relevantes para a história da rede viária do Conventus Bracaraugustanus, região que conta com uma elevada quantidade de marcos miliários, pertencentes a estradas de primeira categoria, autênticas vias atendendo à balizagem contínua dos traçados a partir de Braga, independentemente da jurisdição dos territórios atravessados.

As epígrafes dos miliários tinham a primeira linha, em média, a cerca de um metro e meio de altura, um pouco mais nos grandes miliários, como alguns de Caracala que utrapassam 2,5 metros de altura, como o que existe na Quinta de Santa Catarina, perto de Vila Nova de Famalicão (EE VIII 206). A dimensão das letras diminuía progressivamente de cima para baixo, com excepção da linha que continha a indicação da distância, normalmente a última, que costumava ser maior que as restantes para facilitar a leitura em movimento. Inscrições longas, como a do miliário de Maximino e Máximo que transcrevemos, obrigavam o viajante a parar, caso estivesse interessado na leitura completa do texto. As inscrições viárias contribuiram largamente para a difusão de uma cultura básica latina, tendo constituído os miliários, nos mais afastados meios rurais do Império, a primeira forma de alfabetização e comunicação escrita, como é geralmente aceite.

O contributo de Mário Saa para o estudo dos miliários do território português, para além de todas as polémicas que suscitou, justificadas ou não, foi importante, quer registando peças entretanto desaparecidas, confirmandos os receios de Martins Capela e do próprio Saa quanto ao respeito, ou falta dele, por estes monumentos essenciais da romanização (Capela 1895: 263; Saa 1956: 7-8, 55), quer deixando-nos referências precisas aos locais de achado e leituras das epígrafes, quer recolhendo marcos como os três que se encontram a salvo na colecção da Fundação Paes Teles / Mário Saa (Encarnação 1995: 639-644), um de Tácito, da via Olisipo-Scallabis-Emerita, outro de Constantino, achado perto da Lagoa Grande, na Chamusca, provavelmente da mesma estrada, e um fragmento, onde apenas se lê a letra $\mathrm{C}$, cuja origem permanece obscura.

Entre os muitos miliários que Saa referiu a propósito da estrada Ebora-Pax Iulia, apresentando, inclusive, fotos de alguns, destacamos o marco de Maximino e Máximo, que Mário Saa viu no Xarrama servindo de poldra, perto do Porto da Calçadinha, Camoeira (Saa 1963: 238-240; Sillières 1984: 55-67; Encarnação 1984: 724), marco que indica a milha XI contada a partir de Évora, distância real entre o local do achado e a 
cidade. Cremos que o monumento remonta a 236, atendendo à simplicidade das titulaturas. A referência fecerunt que antecede a indicação da distância, limitada ao numeral, deve entender-se em relação a algum trabalho pontual, não à construção da via. Este marco teve um fim feliz, ao contrário de outros que Saa registou na mesma estrada. Foi levado para o parque de máquinas da Junta Autónoma das Estradas, em Évora, por volta de 1982, encontrando-se hoje no exterior do edifício da Administração das Estradas de Portugal, na mesma cidade, cuidadosamente preservado (Fig.9). A leitura proposta por Mário Saa não corresponde completamente ao que se pode ler, sem problemas, no marco (IRCP 664a), pois a situação em que o miliário se encontrava impedia a leitura de forma conveniente. Neste monumento os nomes dos governantes sofreram também o efeito da damnatio memoriae, tendo sido picados, circunstância que, uma vez mais, relaciona directamente os miliários com a história política do Império. A via Ebora-Pax Iulia, já indicada por Emil Hübner no mapa que ilustra o Corpus Inscriptionum Latinarum, foi curiosamente ignorada durante muito tempo pelos arqueólogos portugueses.

No Ervedal conservam-se dois marcos pertencentes à via Olisipo-Scalllabis-Abelterium-Emerita, cujo traçado levanta ainda várias dúvidas, sobretudo quando se trata de localizar algumas das estações viárias. O primeiro é um elegante marco de Tácito (fuste reutilizado ?) achado em 1951 a uns seis quilómetros a oriente de Ponte de Sor, no lugar de Nossa Senhora dos Prazeres (Saa 195: 235, 275; Encarnação 1995: 639-641). Os miliários de Tácito são raros na Hispânia, faltando por completo na longa série de monumentos registados na via Emerita-Asturica, valorizando o seu achado nesta estrada lusitana, onde há referências a outros (IRCP 665, 666, 667). O miliário remonta, de acordo com a titulatura, aos finais de 275. A inscrição, nomeando o imperador em dativo, encontra-se completa, sem indicação de distância, como sucede nos restantes miliários que referimos, podendo ter sido pintada. Eis o texto, de gravação um tanto descuidada, irregular: $\operatorname{Im}[p]$ / Caes / Marco / Claudio / Tacito / Pio Felici / Invicto / Aug P P / II Cos (Fig.10). O imperador Tácito governou apenas alguns meses, entre Setembro de 275 e Abril de 276, quando foi assassinado num pronunciamento militar. Tácito era descendente do historiador romano com o mesmo nome e a sua actividade viária na Hispânia parece ter-se concentrado nos eixos Olisipo-Emerita, Olisipo-Bracara, Emerita-Bracara e Bracara-Asturica. No território actualmente espanhol conhece-se apenas um miliário deste imperador, em Tricio, na Rioja (CIL II 4879). 
O segundo miliário desta via recolhido por Mário Saa e conservado no Ervedal reduz-se a um fragmento, proveniente da Lagoa Grande, freguesia de Ulme, e pertence também à mesma via. Conserva parte da inscrição, de má qualidade, composta por cinco linhas e restos de uma sexta linha, de difícil interpretação. O miliário é do imperador Constantino e certamente ter-se-ia perdido se Mário Saa o não tivesse recolhido: $D($ omino $) N($ ostro $)$ I Fla(vio) Valerio Cons/tantino No/bilisimo Caes(ari) vel Victori/ ac fortisimo / [...]. Como Encarnação sugere, cremos que na sexta linha se pode restituir a palavra Victori, em lugar de Caesari como propôs Saa (Saa 1956: 234-235; 1963: 154; Encarnação 1995: 642-643). O traçado exacto desta estrada suscita ainda muitas questões, tanto mais que os miliários que dela se conhecem são quase todos relativamente tardios. A rede viária romana no Alto Alentejo era particularmente densa, contando as estradas principais, como esta, com diversos deverticula também dotados de miliários, circunstância que complica a interpretação dos traçados (Alarcão 2006: 211-251; Mantas 2008-2009: 243-245). Devemos ter em conta que a concentração de miliários numa determinada zona pode reflectir a travessia de um território específico, mesmo que a estrada não toque na sede da civitas, não indicando, portanto, as milhas em relação a esse centro. $O$ contributo dos miliários é, apesar de tudo, incontornável quer na reconstituição dos percursos, quer no estabelecimento da sua cronologia, assumindo-se como fontes essenciais, históricas e arqueológicas.

A propósito do miliário da Lagoa Grande fez Mário Saa algumas contundentes observações acerca da falta de interesse pela conservação destes monumentos, dos quais muitos dos que foram registados a partir do século XVI se perderam definitivamente, incluindo parte dos que foram vistos por Capela, no século XIX, e por Saa no século XX. A conservação dos miliários não levanta problemas de maior, pois a sua dimensão reduzida facilita, se necessário, a deslocação para local abrigado. Embora a conservação no local seja preferível, uma vez que o miliário se integra frequentemente num ambiente construído ao longo de séculos e parte integrante de um imaginário histórico-cultural complexo, a verdade é que essa solução nem sempre nos parece adequada, embora haja actualmente uma certa tendência, na maior parte dos casos muito infeliz, para manter os monumentos epigráficos ao ar livre, com resultados desastrosos, que vão desde o roubo dos mesmos até ao grafito difícil de eliminar, para além da permanente acção nociva dos agentes atmosféricos, hoje muito mais agressivos que em séculos passados. 
Assim, parece-nos medida de bom senso recolher os miliários em museus ou noutros locais onde possam ser estudados e apreciados, subtraindo-os aos diversos perigos a que, de outra forma, ficam sujeitos. Esta solução não lhes retira o valor como elementos de interesse turístico, pois podem ser substituídos, com vantagem, por cópias devidamente sinalizadas e dotadas de informação adequada, como sucede, por exemplo, em certas vias romanas do Limes germânico e, na Península Ibérica, na via Emerita-Asturica, parte da qual é constituída pela célebre Via de la Plata (Fig.11). Em certas condições é viável manter os marcos, nomeadamente quando anepígrafos, no local onde se encontram, ou quando se encontram em áreas protegidas, como parques naturais ou semelhantes. Seja como for, a preservação física do monumento deve prevalecer em todas as circunstâncias.

Como os miliários são fontes históricas e arqueológicas fundamentais (Encarnação 2011: 385-394), parece-nos absolutamente necessário que os investigadores disponham de catálogos exaustivos e cientificamente elaborados, substituindo os levantamentos do século XIX, como o inestimável trabalho de Emil Hübner, e a enorme bibliografia dispersa produzida desde então. Ainda que a nova edição do volume XVII do Corpus Inscriptionum Latinarum se revele do maior interesse, edição que aliás tarda a concretizar-se, julgamos que um catálogo dos miliários do território português, mais acessível que a grande obra de inspiração germânica, seria particularmente útil aos investigadores peninsulares, pois não esqueçamos que as vias romanas existentes no território nacional muitas vezes têm troços que se desenvolvem no país vizinho. Ainda que as condições presentes não se mostrem particularmente propícias aos estudos históricos e às humanidades em geral, a não ser em certos casos de evidente interesse político ou económico, pensamos desenvolver um projecto que conduza à elaboração de um catálogo que recolha a epigrafia viária da Lusitânia ocidental.

Os miliários, depois de terem contribuído para dar sentido ao mundo, facilitando a sua interpretação através de dados objectivos, domesticando o espaço, humanizando-o, contam-nos hoje uma história feita de muitas histórias. Saibamos nós ouvi-las sem preconceitos, olhando-os não como simples pedras de um tempo morto, desprovido de significado, mas antes trazendo-os novamente à vida, como testemunhos de outro tempo nosso, novamente com sentido, sobretudo neste mundo em que a Hybris levou às consequências de sempre, ignoradas as mensagens dos visionários e da História. Como escreveu o poeta Christian Morgenstern, a propósito de um marco quilométrico: Ein uns völlig fremd Geschehen / Erst das Auge schafft die Welt (Morgenstern 1967: 168). 


\section{Notas}

1 - Abreviaturas no texto: Itinerarium Antonini Augusti (ed. Wesseling), Amesterdão, 1735 (= It. Ant.); Corpus Inscriptionum Latinarum, Berlim (= CIL); Ephemeris Epigraphica, Berlim (=EE); José d'Encarnação, Inscrições romanas do Conventus Pacensis, Coimbra, $1984(=I R C P)$. Agradecemos cordialmente ao Dr. Luís Madeira a preparação das figuras deste artigo, resultante de uma conferência proferida na Fundação Arquivo Paes Teles / Mário Saa, no Ervedal, em Junho de 2011.

2 - Trata-se, seguramente, do estádio alexandrino, equivalente a 185 metros.

3 - Estes miliários de Augusto, com a contagem da distância a partir de Mérida, sugerem que o eixo principal de penetração na Beira portuguesa não era ainda a via da Ponte de Alcântara.

4 - Os marcos foram encontrados nas Ramalheiras (Cabecinhos), um pouco a nordeste de Alfeizerão, de acordo com amável informação do Snr. Carlos Almeida, neto do achador.

5 - A obra de Goldsworthy, embora não desenvolva teses particularmente inéditas, permite compreender as irreversíveis e intemporais consequências de arrastadas crises de autoridade e financeiras. As teses sobre as causas da decadência e queda de Roma, entre credíveis e simplesmente fantasiosas, foram enumeradas numa longa lista por Alexander Demandt.

\section{Bibliografia}

ALARCÃO, Jorge de (2006), "As vias romanas de Olisipo a Emerita Augusta", Conimbriga, 45: 211-251.

ÁLVAREZ MARTÍNEZ, J. M. / BASARRATE, T. Nogales (2003), "Calzadas de Lusitania: programación e ideología imperial", Las Comunicaciones en Lusitania Romana, Mérida: 255-276.

ALMEIDA, C. A. Brochado de (1979), “A rede viária do conventus Bracaraugustanus. Via Bracara Asturicam quarta", Minia, 1979: 61-163.

ALMEIDA, Fernando de (1956), "Marcos miliários da via romana Aeminium-Cale", O Arqueólogo Português, $2^{\mathrm{a}}$ série, 3:111-113.

AMIANO MARCELINO, Epit., 15, 2, 17.

ARZONE, Antonella (2011), "Alcune considerazioni sulle immagini di pietre miliari e sui riferimenti alle strade nel documento monetale", I Miliari Lungo le Strade dell'Impero, Caselle di Somma Campagna: 77-92.

BLÁZQUEZ, Antonio (1932), "Diversas longitudes de la milla romana", Boletín de la Real Academia de la Historia, 100: 43-57.

BRONSEVAL, Claude de (1970), Peregrinatio Hispanica (introd., tradução e notas de Dom Maur Cocheril), 2, Paris.

CAPELA, M. Martins (1895;1987²), Miliários do Conventus Bracaugustanus em Portugal, Porto. 
CARNEIRO, André (2008), Itinerários romanos do Alentejo. Uma releitura de "As Grandes Vias da Lusitânia. O Itinerário de Antonino Pio" de Mário Saa, cinquenta anos depois.

CHEVALLIER, Raymond (1972), Les voies romaines, Paris.

COLMENERO, A. Rodriguez / SIERRA, S. Ferrer / ASOREY, R. Álvarez (2004), Miliarios e outras inscricións viarias romanas do noroeste hispánico, Santiago de Compostela.

O Comércio do Porto (1985): edição de 19 de Março.

Cod. Theod., 15, 3, 1 .

DEMANDT, Alexander (1984), Der Fall Roms: Die Auflösung der römischen Reiches im Urteil der Nachwelt, Munique.

DUNCAN-JONES, R. (1974), The Economy of the Roman Empire. Quantitative Studies, Cambridge.

ENCARNAÇÃO, José d' (1984), Inscrições romanas do Conventus Pacensis, Coimbra, 1984.

ENCARNAÇÃO, José d' (1995), “A colecção epigráfica de Mário Saa no Ervedal”, Humanitas, 47: 629-645.

ENCARNAÇÃO, José d' (2010), “O miliário como documento”, Pallas, 82: 385-394.

ÉTIENNE, R. / FABRE, G. (1976), Fouilles de Conimbriga, II, Paris.

FRONTINO, De Aquae.,161.

GOLDSWORTHY, Adrian (2010), O fim do Império Romano, Lisboa.

GRENIER, Albert (1934), Manuel d'archéologie galo-romaine, II, Les routes, Paris.

HOLANDA, Francisco de (1984), Da fábrica que falece à cidade de Lisboa (introd., notas e comentários de J. F. Alves), Lisboa.

KLEINER, F. S. (1991) "The trophy on the bridge and the Roman triumph over nature", L'Antiquité Classique, 60: 182-192.

KOLB, Anne (2011), "Miliaria: ricerca e metodi. L'identificazione delle pietra miliari”, I Miliari Lungo le Strade dell'Impero, Caselle di Somma Campagna: 17-28.

KÖNIG, I. (1973), “Zur Dedikation römischer Meilensteine”, Chiron, 3: 419-427.

LAMBRINO, Scarlat (1956), "Les inscriptions latines inédites du Musée Leite de Vasconcelos", O Arqueólogo Português, 2a série, 3: 14-17.

LOT, Ferdinand (1968²), La fin du monde antique et le début du moyen âge, Paris.

LUZ, Frei Isidoro da (1642), Relação verdadeira do descobrimento dos Santos Mártires, Miscelânea $\mathrm{n}^{\mathrm{0}} 7$, Biblioteca Nacional da Ajuda.

MANTAS, Vasco (1985), Dois novos miliários do território de Conimbriga, Biblos, 61, 1985: 159-179. 
MANTAS, Vasco (1986), Um miliário de Adriano em Alfeizerão, Conimbriga, 25: $213-225$.

MANTAS, Vasco (1996), A rede viária romana da faixa atlântica entre Lisboa e Braga, Coimbra (dissertação de doutoramento policopiada).

MANTAS, Vasco (2000), “A via romana Bracara Augusta-Cale: traçado, funções e influência no povoamento regional”, Revista de Guimarães, 110: 53-87.

MANTAS, Vasco (2008-2009), “A rede viária romana em Portugal. Estado da questão e perspectivas futuras”, Anas, 21-22: 245-272.

MANTAS, Vasco (2010), Os Lares Viales na Lusitânia, Vialibus, 2: 13-34.

MARQUES, José (1997), "Viajar em Portugal nos séculos XV e XVI”, Revista da Faculdade de Letras do Porto, 2a série, 14: 91-121.

MORÁN, César (1949), La calzada romana “La Plata” en la província de Salamanca, Madrid.

MORGENSTERN, Christian (1967), “Der Meilenstein”, Anthologie bilingue de la poésie allemande (coord. René Lasne), 2, Verviers.

MORO, L. (1983), "I denari di L. Vinicius del tesoretto di Cinto Caomaggiore (Venezia) e il miliarium aureum", Archeologia Veneta, 6: 77-80.

MÜLLER-WIENER, W. (1977), Bildlexikon zur topographie Istanbuls: Byzantion, Konstantinupolis, Istanbul bis zum Beggin d. $17 \mathrm{Jh}$, Tübingen.

PEKARY, Thomas (1968), Untersuchugen zu den römischen Reichsstraßen, Bona.

PENSA, Marina (1979), “Genesi e svilupo dell'arco onorario nella documentazione numismatica”, Studi sull'Arco Onorario Romano, Roma: 19-27.

POLÍBIO, III, 39, 8.

Portugaliae Monumenta Historica (1856), I, Leges, Lisboa.

RICHARDSON, L. (1992), "Milliarium Aureum”, A New Topographical Dictionary of Ancient Rome, Baltimore: 254.

ROLDÁN HERVÁS, J. M. (1975), Itineraria Hispana. Fuentes antiguas para el estudio de las vías romanas en la Península Ibérica, Madrid-Granada.

ROLDÁN HERVÁS, J. M. (2005), El Camino de la Plata. Estado da la cuestión, Anas, 18, 2005: 11-27.

SAA, Mário (1956), As grandes vias da Lusitânia. O Itinerário de Antonino Pio, I, Lisboa.

SAA, Mário (1963), As grandes vias da Lusitânia. O Itinerário de Antonino Pio, IV, Lisboa.

SALAMA, Pierre (1951), "Les bornes milliaires de Djemila-Cuicul et leur intérêt pour l'histoire de la ville", Revue Africaine, 95: 213-217. 
SALWAY, Benet (2001), "Travel, itineraria and tabellaria", Travel and Geography in the Roman Empire, Londres-Nova Iorque: 48-54.

SILLIÈRES, Pierrre (1984), "Deux nouvelles bornes milliaires de la voie Ebora-Pax Iulia”, Conimbriga, 33: 55-67.

SILLIÈRES, Pierre (1990), Les voies de communication de l'Hispanie méridionale, Paris.

SILVA, A. C. Ferreira da (1981-1982), "Novos dados sobre a organização social castreja", Portugália, 2-3: 83-96.

STERPOS, D. (1971), La route romaine en Italie, Roma.

SUETÓNIO, Tib., 26.

SUSINI, Giancarlo (1982), Epigrafia romana, Roma.

SUSINI, Giancarlo (1988), "Compitare per via. Antropologia delle lettore antico. Meglio, delle lettore romano”, Alma Mater Studiorum, I, 1, Bolonha: 1988: 105-124.

TORRES, Carmen Puerta (1995), Los miliarios de la Vía de la Plata, Madrid.

TRANOY, Alain (1981), La Galice romaine. Recherches sur le nord-ouest de la Péninsule Ibérique dans l'Antiquité, Paris.

WHEELER, Mortimer (1964), Roman Art and Architecture, Londres.

WICKERT, L. (1933), "De nonullis milliariis Bracarensibus", Homenagem a Francisco Martins Sarmento, Guimarães: 442-448. 
FIGURAS 

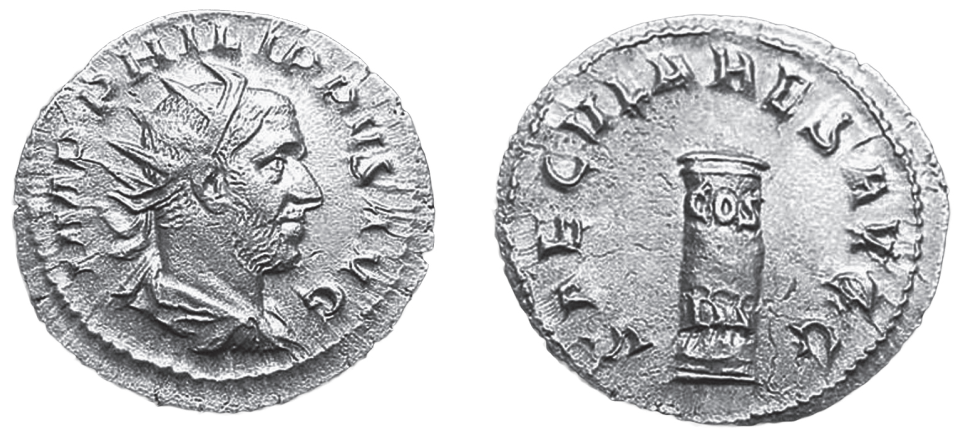

Fig.1 - Antoniniano de Filipe, o Árabe, comemorativo dos festejos do milenário de Roma.

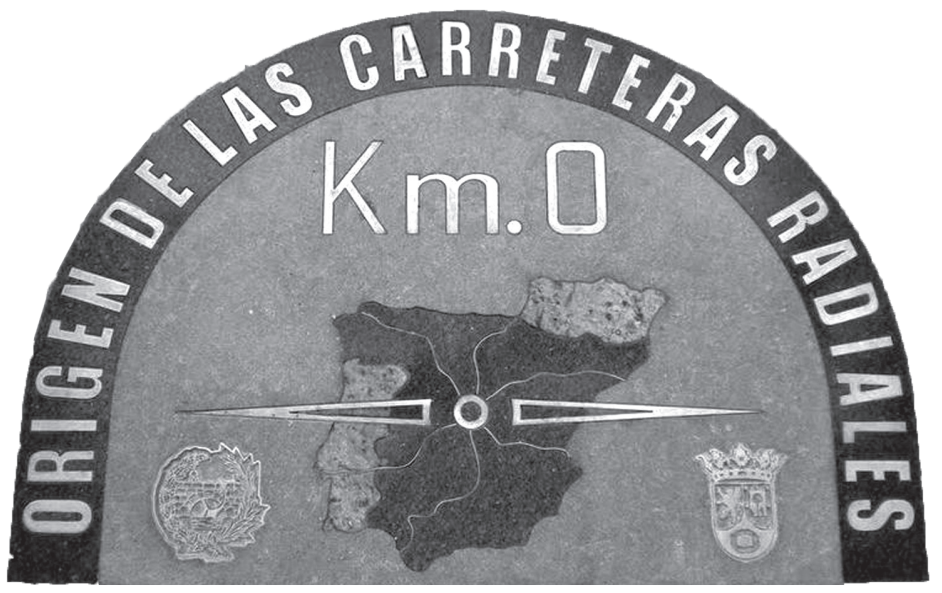

Fig.2 - Ponto de contagem inicial das distâncias das estradas radiais, Madrid. 


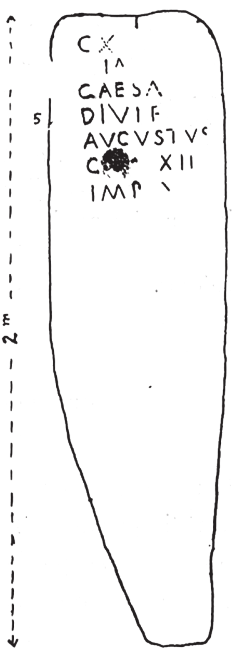

3. - Pilier en granit de couleur claire, dont l'extrémité inférieure a été amincie pour qu'il pût être fiché en terre. C'est un milliaire (Fig. 3).

Dimensions: hauteur $2^{\mathrm{m}}$, largeur $0^{\mathrm{m}} 50$, épaisseur $0^{\mathrm{m}} 30$.

Inventaire E 6818.

Bien que très endommagés, les caractères con. servent leur beauté.

La surface est devenue très fruste par frottement: le milliaire a dû servir de pavage à une époque plus récente. Plusieurs lettres ont disparu et, des deux lignes du début, il ne reste que quelques vestiges.

L. 2: CX, la seconde lettre est très effacée, mais assez visible.

L. 7: à la place de l'O de COS, il y a un large trou rond; sur son rebord, à droite, s'est conservée l'extrémité supérieure de l's.

Après la 1.8 , il n'y a plus aucune trace de lettres.

Fig.3 - O miliário de Augusto, achado em Alfaiates (segundo Scarlat Lambrino).

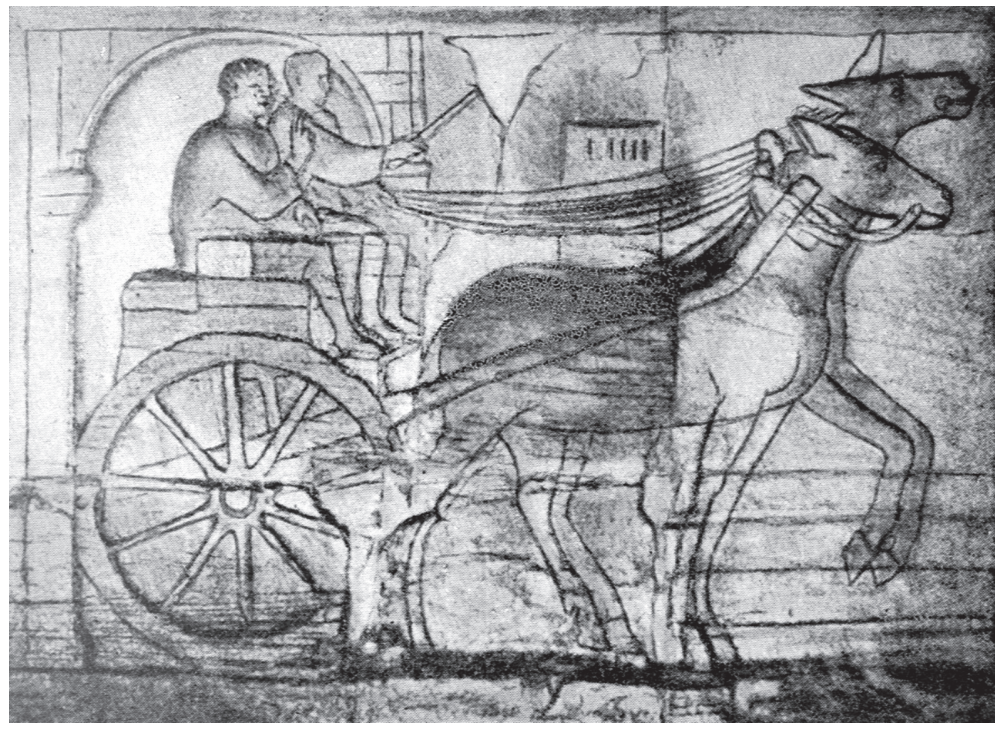

Fig.4 - Baixo relevo do monumento funerário de Igel. 

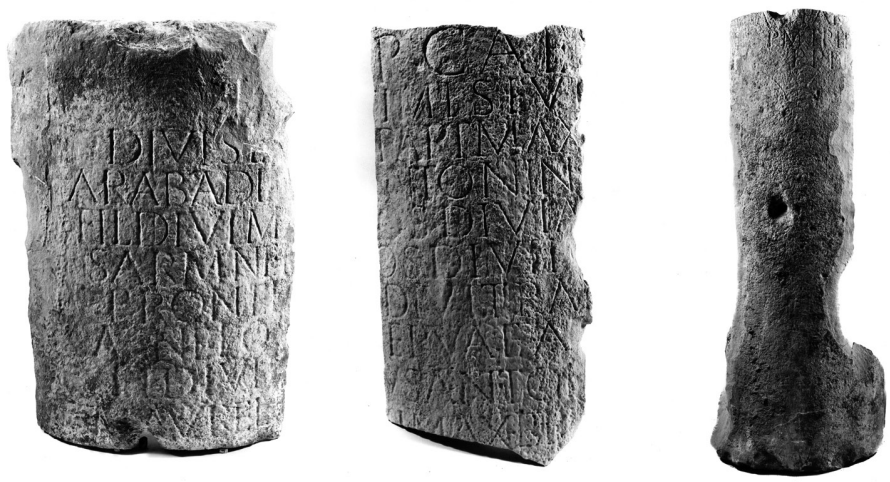

Fig.5 - Miliário de Caracala, quebrado para reutilização, achado em Soure.

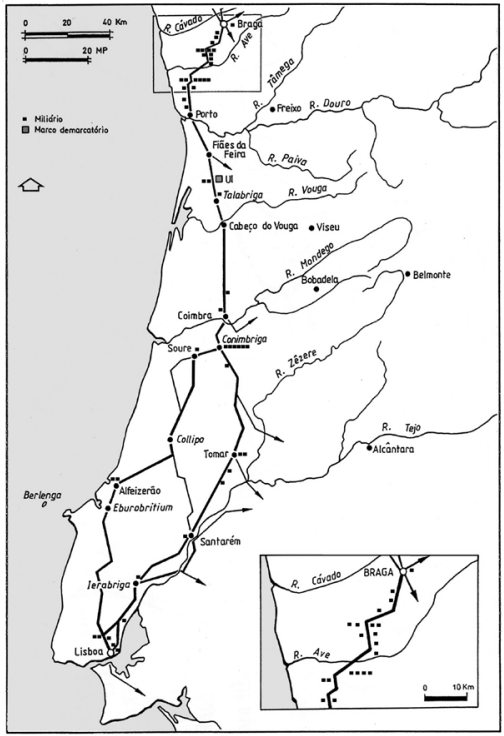

Fig.6 - Distribuição dos miliários registados nos itinerários Olisipo-Bracara Augusta e Olisipo-Conimbriga. 


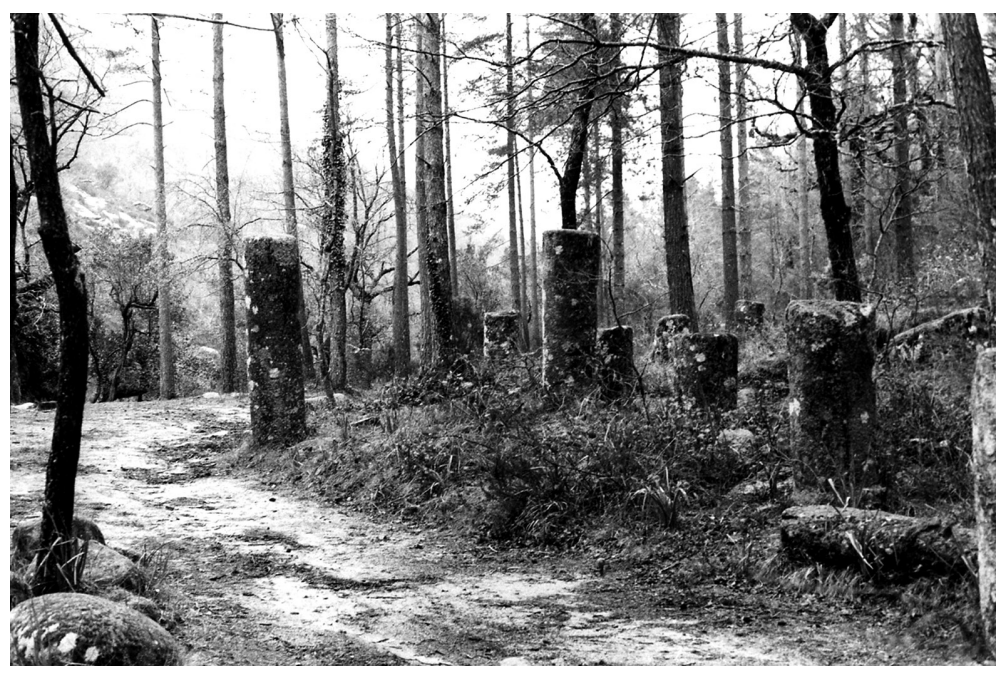

Fig.7 - Ninho de miliários da Via Nova entre Bracara e Asturica, na Portela do Homem.

4682 Salmanticae, 'en la casa del conde de

Fuentes' Dáv. Postea en el puente sobre

Tormes' Ponz. Nescio num adhuc extet.

IMP.CAESAR DIVI TRAIANI·PAR
TICI $\cdot \mathrm{F} \cdot \mathrm{D} \cdot \mathrm{NERVAE} \cdot \mathrm{NEPOS}$
ADRIANVS AVG $\cdot$ PONT $\cdot$ MAX
TRIB $\cdot$ POT $\cdot \mathrm{V} \cdot \mathrm{COS} \cdot \mathrm{III} \cdot \mathrm{RESTI} / I$
TVIT

CXLIX

Gil Gonzalez Dávila Salamanca f. 128 (inde Bibranus ms. Liegn. f. 203 v.; per Martinum Maffei M. V. 424, 9; Ponz 12, 258; Masdeu 5, 291, 241).

Emendatio in promptu est, cf. n. 4669.

Miliarium n. CLVII quaere inter suspectas n. $453^{*}$.

Fig.8 - Epígrafe de um miliário de Adriano achado em Salamanca (CIL II 4682). 


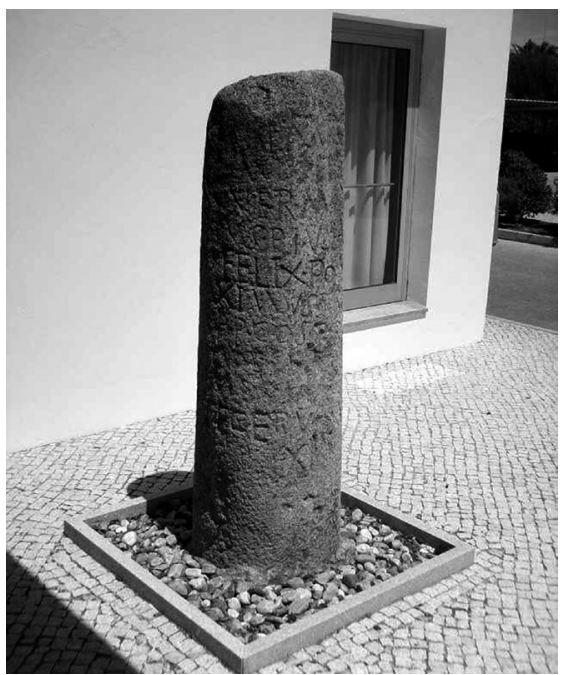

Fig.9 - O marco miliário da milha XI da via Ebora-Pax Iulia (Porto da Calçadinha / Camoeira).

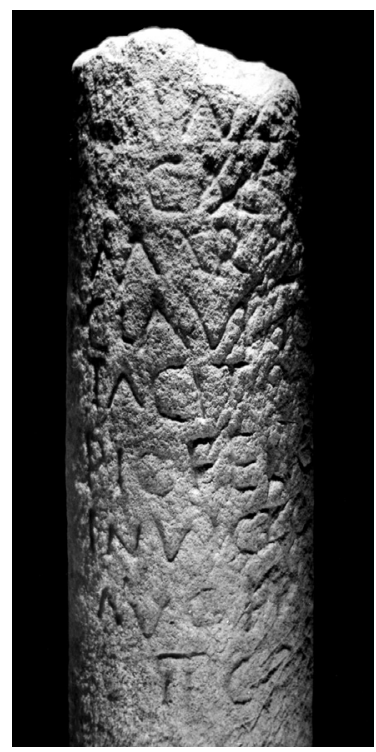

Fig.10 - Miliário de Tácito, recolhido por Mário Saa na Nossa Senhora dos Prazeres. 


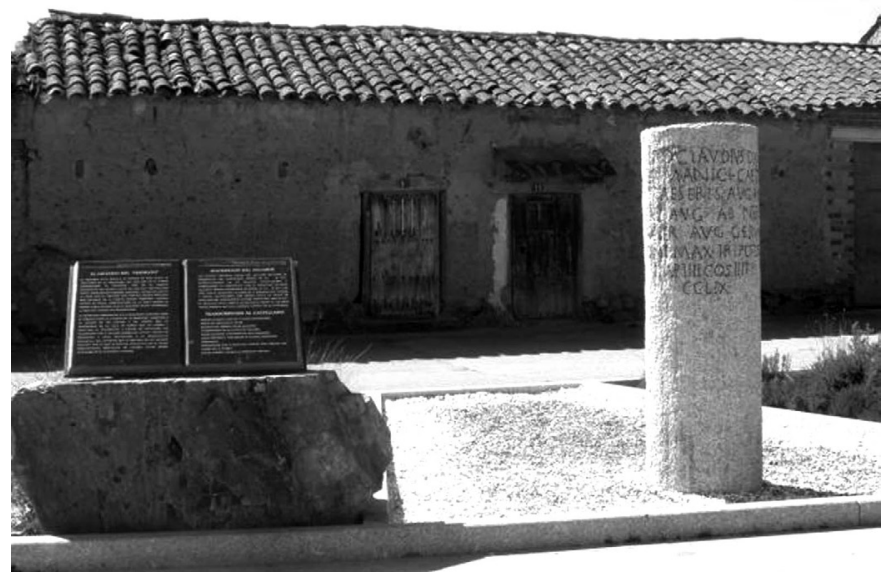

Fig.11 - Cópia do miliário de Miles da la Polvorosa, da via Emerita-Asturica, com painéis explicativos, levantado no local de achado do monumento. 